International Journal of Linguistics, Literature and Translation

ISSN: 2617-0299 (Online); ISSN: 2708-0099 (Print)

DOI: $10.32996 / \mathrm{ijllt}$

Journal Homepage: www.al-kindipublisher.com/index.php/ijllt

IJLLT

\title{
Moderating Opposition and Shaping Political Settlement in the US Presidential Speech on the Military Action in Syria: A Critical Discourse Analysis
}

\author{
Yasser A. Gomaa ${ }^{1} \mathbf{8}(\mathrm{D}) \square$ and Mervat Isa Albufalasa ${ }^{2} \mathbf{8}$ (D) \\ ${ }^{7}$ Associate Professor of Linguistics, Department of English Language and Literature, College of Arts, Assiut University, Egypt \& \\ University of Bahrain, Kingdom of Bahrain \\ ${ }^{2}$ Assistant Professor of Linguistics, Department of English Language and Literature, College of Arts, University of Bahrain, \\ Kingdom of Bahrain \\ $\triangle$ Corresponding Author: Yasser A. Gomaa, E-mail: gomaa@aun.edu.eg
}

\section{ARTICLE INFORMATION}

Received: March 08, 2021

Accepted: April 15, 2021

Volume: 4

Issue: 4

DOI: $10.32996 /$ ijllt.2021.4.4.11

\section{KEYWORDS}

Presidential Speech, Barack Obama, military Action in Syria, critical discourse analysis, ideology, linguistic devices.

\section{ABSTRACT}

This study aims to analyze Barack Obama's speech on Syria delivered on September 10, 2013 in response to the chemical attacks launched against Damascus on August 23, 2013. It employs Fairclough's (2001) framework of Critical Discourse Analysis (CDA) to bring out the ideological polarization latent in the language of Obama by investigating the linguistic devices used to stir emotions in listeners to adopt certain stands or take certain action. It also posits three questions to investigate how Obama's language has been used to display the nature of the U.S. political discourse during the Syrian crisis, explore the ideological component enshrined in Obama's language, and cast light on the typical discourse strategies used by Obama to appeal to the international community to lead a coalition against Syrian regime. The analysis of Obama's speech reveals the ideological opposition to implicating Americans and their allies solely in toppling Al-Assad's regime under the pretext of being preoccupied with quelling violence and establishing peace in the world. The analysis also demonstrates that Obama has availed himself of many linguistic devices such as lexical manipulation, metaphorical expressions, personal pronouns, parallelism, and rhetorical questions to rally support for the US military action in Syria.

\section{Introduction}

Language is a contrivance that shapes reality and influences the perceptions of mankind. It is a means of expressing "different kinds of ideologies, attitudes, hostility, hatred, and other functions (Suleiman, 2003, p. 114). Reyes-Rodríguez (2006) and Lakoff (1995) maintain that language is a means for fostering nationalism among the in-group members. In like manner, Nguyen (2012), Escudero (2011), Nhat (2008) and Heradstveit and Bonham (2007) assert that language is an instrument that boosts good relationships. Language users do not use words or phrases in isolation, but according to the social, cultural and psychological domains they live in. They take advantage of vivid expressions, passionate speeches and ardent stances to delicately get the addressees' attention, and to develop a solid relationship with their audience. Political leaders, like presidents, endeavor to linguistically manipulate the public in order to convince them to agree with and support their policies, to perform certain actions, to build close relationships with them, and to continue to wield power. Referring to this, Lakoff (1995) claims that language can be used as "an essential source of fostering solidarity amongst the receivers through the use of linguistic means that blur the differences between the different social sectors of the same nation" ( $p$.11). Accordingly, metaphorical expressions, i.e. the family, can be used to describe in-group identities, to strengthen the feelings of national solidarity among the people of the same nation. In this respect, politicians play a key role.

Presidential speeches have been subjected to different types of analysis by linguists, sociolinguists, political scientists, and historians. Using the tools of Critical Discourse Analysis (CDA), linguists focus on different aspects in the speeches of political

\section{K C AL-KINDI CENTER \\ $\mathbf{R}$ D FOR RESEARCH AND DEVELOPMENT}

Your gateway to world-class research

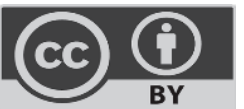

Published by Al-Kindi Center for Research and Development, London, United Kingdom. Copyright (c) the author(s). This open access article is distributed under a Creative Commons Attribution (CC-BY) 4.0 license 
leaders. They investigate the discourse features that certain texts manifest together with the underlying ideologies of political readers. Specifically, the politicians' utilization of various linguistic features like the use of words, which have positive denotations, to describe their supporters (e.g., us), and words that have negative denotations to describe their opponents (e.g., them). These words are labeled as "positive us" and "negative them" (Van Dijk, 1993, p. 263). Matić (2012) and Wang (2010) argue that these labels, which are not arbitrary but ideologically instigated, reflect ideological decisions. Referring to this point, Sheyholislami (2010) contends that "The way we write, and what we say, is not arbitrary - it is purposeful whether or not the choices are conscious or unconscious" (p. 13).

The study at hand sets out to analyze the speech delivered by Barack Obama, the former president of the United States of America, on September 10, 2013 on Syrian Crisis following the perspective of CDA. It is an attempt to shed light on the nature of the US president's political discourse as well as the different ways by which language is employed to depict Bashar al-Assad, the President of Syria, his regime and the chemical attack on Syria on August 21, 2013. Moreover, it explores the role of language in constructing solidarity amongst Americans and the international community, focusing on the use of national and international solidarity expressions, emotive expressions used to sway target recipients to adopt certain attitudes, or beliefs. In practical terms, this study is purported to answer three major questions, namely (1) How was Obama's language used to display the nature of the US political discourse during the Syrian crisis?, (2) What was the ideological component enshrined in Obama's language over the Syrian crisis?, and (3) What were the typical discourse strategies used by Obama to persuade the world community or to build an international coalition against the Syrian regime?

\section{Literature review}

The speeches of political leaders have been subjected to different types of analysis and investigation by historians, political scientists, linguists, sociolinguists, and psychologists. This section presents a brief account of some available studies which have examined how socio-political relations and ideological power wielding are reflected in political speeches, especially those delivered by Barack Obama.

Some studies have investigated the use of metaphorical expressions in political discourse. Escudero (2011), for example, has investigated Obama's inaugural address during the celebration of the presidency after the elections. He has come up with the fact that Obama has struck the target audience as persuasive through the extensive use of captivating metaphors, which "converted abstract notions into concrete ones related to human body and natural phenomena, to directly engage the emotions of Americans" (p. 48). Further, Escudero argues that suffusing Obama's speech with the values and ideals of America in a figurative manner has made him strike the right note with the audience. His verbal dexterity has manifested itself in the many linguistic devices and features he has employed. To illustrate, Obama has employed "evaluative metaphors" that describe political activity. This refers to the positive connotations of creation and building and the negative ones of destruction and conflict.

In addition, Nguyen (2012) has analyzed the linguistic features used in Obama's speeches. He concludes that metaphors have been the most frequently used feature, followed by repetition and euphemism. Examples of the use of metaphors include personifying the American economy as a person and as a house. Those metaphorical expressions have been instrumental in highlighting Obama's messages to Americans. In the same vein, euphemism has also been used to create visual effects, while repetition has been used to place great emphasis on his messages and show his emotions. For the purpose of drawing support and approval from his audience, he deftly employs rhetorical questions.

In a comparative study, Matić (2012) has tackled the ideological discourse structures in the political speeches of the Republican Party candidate John McCain and the Democratic Party candidate Barack Obama in the final days of the 2008 American presidential election campaign. The results have indicated that these speeches were socially, ideologically and personally oriented. Moreover, both candidates have availed themselves of similar linguistic devices for ideological representations. Assertive speech acts were used by both of them in order to obligate a speaker to the truth of the expressed proposition. Moreover, the ideological representation of positive 'us' was highly manifested by McCain and Obama through linguistic devices as the exclusive and the inclusive 'we' or ' $\mathrm{I}$ ' and metaphors. Furthermore, the analysis has showed that McCain has tended to use many structures and rhetorical devices. In regard to Bush's administration, McCain has resorted to metaphors, metonymies and hyperbole in speech acts of objection. Also, he has employed nominal phrases, passive forms, structures of indefinite meaning, presuppositions and implicatures to criticize indirectly and implicitly Bush's administration. Besides, he has deployed assertive speech acts to warn the public against the democrats. He has also produced out of his armory many devices such as sophism, misinterpretation and presentation of untrue information about the other to expose the shortcomings of democrats. As for Obama, the analysis has shown that he has deftly used metaphors, metonymies, presuppositions and implicatures to strike a chord with his target audience. He has also employed assertive speech acts that have contained open criticism of his opponents. In addition, the inconsistency of the political behavior of his opponent has been criticized through using intertextual examples. 
Some other studies have investigated the impact of lexical items in political speeches. In a study conducted by Sarfo and Krampa (2012), they have employed CDA to analyze the speeches of Obama and Bush on terrorism. They argue that "Bush and Obama projected terrorism negatively while they projected anti-terrorism positively by carefully selecting emotionally charged vocabulary and expressions" (p. 378). Their vocabulary items were dominantly nouns (e.g., attack, enemy, danger, tragedy) and verbs (e.g., kill). Their phrasal categories included verb phrases that often followed by noun phrases, adverbial phrases, prepositional phrases, and adjectival phrase. They have used all types of sentences, i.e. simple, compound and complex. However, complex sentences were dominant in their speeches because of the complex nature of the horrendous acts committed by terrorists. They concluded that the political discourse of both presidents has been characterized by linguistic expressions carefully chosen to achieve their ideological aims and to produce persuasive oratory.

Some other studies have explored the significant usage of lexical items and pronouns in political speeches. Nhat (2008) has examined the persuasive use of rhetorical devices (e.g., pronouns and parallelism). The study has concluded that Obama has manipulated some rhetorical devices in order to make the audience believe and support his ideas and policies. For example, to connote a high degree of intimacy and solidarity, the pronouns 'I' and 'you' have been used as they narrow the gap between the speaker and the listener, and the use of 'we' enhances the intimacy between ' $I$ ' and 'you' which have been employed to help in connecting 'I' and 'you', driving home the feeling that the speaker and the listener have been on the same side. Moreover, Nhat has indicated that Obama has made use of parallelism to elicit sympathy from his audience, and perhaps to make his speech more memorable.

Horváth (2009) has also investigated Obama's inaugural speeches in order to highlight the ideological component enshrined in his language during the economic turmoil. He has explored a number of key ideological components of Obama's speeches such as pragmatism, liberalism, inclusiveness, acceptance of religious and ethnic diversity and unity. Obama's speeches have been laden with these ideological components and have been accentuated by language. For example, Obama has tended to use the first plural pronoun, words like 'nation' and 'new America' and biblical references in order to strengthen the national unity among Americans in facing the financial crisis.

In the same connection, Wang (2010) has used CDA theory and Systematic Functional Linguistics to get to the bottom of the relationship between Obama's texts and his underlying ideology after winning the elections of 2008. He has found out that Obama has opted for simple and colloquial language in order to serve his ideology and influence the audience as well as gain their confidence. He has argued that Obama has extensively used first pronouns 'I' and 'we' together with religious statements or beliefs to bolster public confidence in his administration, unify Americans and raise his approval rating. In addition, he notes that Obama has attempted to use modal verbs with reference to what his administration will do and tenses with reference to what it has achieved and what it is doing right now in order to raise public confidence in his administration in the coming four years.

Similarly, power existed in Obama's interviews before the presidential elections were investigated by Shayegh and Nabifar (2012). They have argued that he has manipulated a strong linguistic mechanism of power in his persuasion modals and strategies. It has been brought to light that in order to curry favor with his target recipients and sway them to vote for him, Obama has employed the pronoun 'l', simple words, short sentences, modals, different tenses, extensive persuasion strategies, religious statements, and long turns. He has opted for expressions that reassert American values and ideals to reach out to voters.

The linguistic features employed in Obama's inaugural address in January 2009 have been investigated by Batluk (2011). She has concluded that Obama has been a skillful orator, manipulating different linguistics means. He has dexterously used, for example, didactic poetry that draws upon repetition and parallelism to be more memorable, to give instruction, and stir sentiments. He has also used lexical items that have more than one meaning, as well as personal pronouns to establish a rapport with his audience. In addition, he has referred to some verses from the Bible to portray himself as the potential savior of the country and the guarantor of its stability. He has also managed to create the emotional atmosphere of the nation as a close-knit family to sow the seeds of love and affection amongst Americans.

One final study conducted by Abdul Wahid (2012) has investigated the use of euphemism in Obama's speeches. She has argued that euphemistic expressions are extensively used in Obama's speeches. It has been found that in order to affect his audience's face negatively, he has frequently employed linguistic expressions that included the tact and approbation maxims, which "minimize cost to other; maximize benefit to other, and minimize dispraise of other; maximize praise of other respectively" (p. 11). In addition, he has deftly used sympathetic expressions for the Americans who have lost their relatives during the war on Iraq. Moreover, he has repeatedly used modest maxim with the aim of minimizing praise of self and maximizing dispraise of self. The researcher has concluded that Obama has kept on praising others and America as an important and dominant country that has a global role in establishing peace all over the world. 
Based on the results of previous studies, it is evident that discourse is socially affected by ideology, and ideology affects the discourse. Political leaders manipulate language in order to achieve their ideological goals and sway the audience to adopt certain actions. The common linguistic devices used in political discourse involve lexicalization, metaphor, euphemism, questioning and personal pronouns.

\section{Theoretical framework}

Obama's (2013) speech on military action in Syria, delivered on the 10th of September after the chemical attack on Damascus in August, was downloaded from https://obamawhitehouse.archives.gov/the-press-office/2013/09/10/remarks-president-addressnation-syria. The grounds and perspectives of CDA were followed to analyze its discourse structure. CDA is "a shared perspective on doing linguistics, semiotic or discourse analysis" (Van Dijk 1993, p. 131). In addition, "One key principle of CDA is that the way we write, and what we say, is not arbitrary-it is purposeful whether or not the choices are conscious or unconscious (Sheyholislami, 2010, p. 13). Besides, Baker and Ellece (2013) point out that CDA "views language as a social practice and is interested in the ways that ideologies and power relations are expressed through language" (p. 26).

The study at hand employs the methodology framework which draws on CDA as conceived by its most outstanding theoretician Norman Fairclough. Specifically, the analysis depends on the principles of Fairclough (2018) who argues that ideology is "located both in the structures that constitute the outcome of past events and the conditions for current events, and in the events themselves as they reproduce and transform their conditioning structures" (p. 308). In other words, ideologies and texts are inseparable, and texts cannot be isolated from ideologies. He also maintains that texts are open to more than one interpretation depending on "what social conventions people are operating with" (Fairclough, 2015, p. 20). It must also be noted that Fairclough (2018) has asserted that the relationship between language and society is 'bi-directional'. That is, social and cultural contexts affect language, and the use of language influences and is instrumental in shaping contexts culturally and socially.

\section{Results and Discussion}

The topic event of Obama's speech on Syrian crisis delivered on 10th September 2013 has stressed the need for a military strike in Syria after accusing the Syrian regime of mounting a chemical attack against Syrians in Damascus. Obama has had the power to launch this strike. However, he has sought approval from the Congress. The following sections analyze the linguistic devices in this discourse in an attempt to throw light on the nature of the US political discourse. Initially, they set out the emotionally charged rhetorical devices employed by Obama to sway his audience to adopt his views and positions. The results of the present study have demonstrated a wide range of rhetorical devices that will be explored below.

\subsection{Use of rhetorical devices for ideological representation}

Rhetoric is important in political speeches as it helps the politician to speak and present ideas in a persuasive manner and communicate their thoughts effectively. Rhetoric is considered powerful if the discourse succeeds in convincing the audience of the targeted aims. The present study shows that emotive expressions have been deliberately chosen by Obama to appeal to the emotions and beliefs of the receivers and thus have a significant impact. This has given Obama a kind of power because he has availed himself of different kinds of devices to influence the feelings or the attitudes of the receivers.

The analysis of Obama's speech reveals the ideological opposition to implicating Americans and their allies solely in toppling AlAssad's regime under the pretext of being preoccupied with quelling violence and establishing peace in the world. Obama's attempt to shape the US public opinion has succeeded as he has dexterously opted for emotionally charged linguistic devices such as lexical terms, phrases and clauses, metaphors and personal pronouns that paint lines among opposing ideologies and describe the in-group members positively and the out-group members negatively. These devices are introduced in CDA as the 'positive us representation and the negative them representation', or the polarization of the in-group and the out-group ideologies' or 'Us and Them'.

\subsubsection{Lexical choice}

In the ideological polarization, lexicalization contributes to influencing the receivers' feelings, beliefs and stands through carefully selecting lexical items that are charged with emotions. Lexical items have communicative purposes thus they create a good impression or a bad picture about different ideologies. Lexical items express and reveal the ideology of the speaker and the ingroup as well as the out-group. In other words, they have an ideological function that helps portray one as more superior than the others that are represented as inferior or mediocre. This strategy creates a division of opposing ideologies, in-groups and out groups, that is, their division between 'good' and 'bad', 'superior' and 'inferior', and 'Us' and 'Them'.

The analysis indicates that Obama has availed himself of certain lexical items in an attempt to differentiate between two ideologies, the in-group and the out-group in order to influence people's beliefs, ideas and political stands. Thus, he tends to describe the ingroup or the victims of the chemical attacks by using positively charged words, and the out-group members have been labeled 
by negatively charged words that expose their brutality and acts of terror. Starting with the opening lines of the speech, the ingroup's identity has been labeled by lexical items that have positive denotations as the adjective (fellow) with reference to Americans and (moderate) with reference to the opposition against the regime and in order to isolate this opposition from that opposition which has been described in the speech as (extremists) or (extremism). The deeds of the in-group have been described by the adjectives (peaceful) and (humanitarian) and in other parts of the speech as (children, civilians, the dying, the wounded and innocent). Meanwhile, the out-group members, i.e. Al-Assad's regime, have been described negatively as (repressive), and their deeds led to a (brutal war). This is also supported by Obama's labeling of leaders like Bashar Al-Assad as (dictators) who commit atrocities and horrifying actions.

The verbs used to refer to the actions of the United States have positive denotation of building and constructing such as the underlined verbs (help, shape and provide), while the verbs used to refer to Al-Assad and his regime have been verbs suggestive of killing and deconstructing as the verbs (kill) and (gassed to death). Obama has opted for the verb (kill) not (die). The verb (kill) means to make someone or something die. Thus, the people did not choose to die, but death was imposed on the lives of people who have been described in the speech as (innocent). Obama has deftly used negative words to describe the nefarious deeds and the actions of Al-Assad and his henchmen. Their deeds have been labeled as (horrifying pictures, massacre, sickening, a crime, danger to our security, a threat) and verbs as those (violate international law) and (threaten allies).

These lexical items play an important role especially at the times of war or brinkmanship as they mold the public opinion. During such times, political leaders utilize lexical items in a manner to peddle political solutions to people and stir them up against their enemy. Obama has also employed a specific set of lexical items to describe the brutality of the chemical weapons and persuade the audience of the pressing need for launching a military strike against those who have authorized such attacks. For example, he has labeled the chemical attack as a massacre that is sickening, a crime and a violation of the laws of war that kills people and children to stir the emotions of the receivers. Obama has apparently labeled the chemical attack committed by the Syrian regime as a crime and a violation of the laws of war to set it apart from the other attacks launched by America under the pretext of establishing peace and democracy. This set of lexical items, singled out by Obama, has helped him secure the approval of Congress and the public to launch the military strike against Al- Assad's regime.

Furthermore, Obama has deftly described the potential military operation against Syria as a (strike) ostensibly because the word operation suggests an action or intervention that takes longer time and strains the American treasury. In the same vein, he has labeled this military strike as (targeted) towards the use of chemical weapons. This means that this military strike will take shorter time compared to other military attacks launched against Iraq or Afghanistan.

One final point that is worth considering is how Obama has addressed himself. In most parts of his speech, Obama has thought highly of himself and introduced himself as the most powerful man using an authoritative tone. He has described himself as (e.g., Commander-in-Chief, and the President of the world's oldest constitutional democracy). A commander-in-chief is a commander in charge of all the armed forces of a country or of all the forces fighting in a particular area or operation. Obama wanted to assert his right to strike Syria even without congressional approval. However, he has referred the decision to the congress just because he has been democratic, and he represents the oldest constitutional democracy.

\subsubsection{Types of sentences, clauses and phrases}

The types of sentences, clauses and phrases which Obama has deftly opted for contribute to projecting the true image of Al-Assad and his regime. To illustrate, Obama has used a variety of sentence types such as simple (e.g., Over the past two years, what began as a series of peaceful protests against the repressive regime of Bashar al-Assad has turned into a brutal civil war; Over 100,000 people have been killed; Millions have fled the country) as well as compound (e.g., America has worked with allies to provide humanitarian support, to help the moderate opposition, and to shape a political settlement; On that terrible night, the world saw in gruesome detail the terrible nature of chemical weapons, and why the overwhelming majority of humanity has declared them off-limits). However, complex and compound-complex sentences have been more frequently used by Obama. This could reflect the complex nature of what happened in Damascus in the aftermath of the chemical attacks and the need for complex language that mirrors chaos and destruction. He might have chosen to interweave the information he provided by adding independent and dependent clauses to serve different functions as (1) combining similar ideas (e.g., It's no wonder, then, that you're asking hard questions. So, let me answer some of the most important questions that I've heard from members of Congress, and that I've read in letters that you've sent to me), (2) comparing and contrasting (e.g., Terrible things happen across the globe, and it is beyond our means to right every wrong. But when, with modest effort and risk, we can stop children from being gassed to death, and thereby make our own children safer over the long run, I believe we should act), (3) conveying cause and effect (e.g., Shortly after those rockets landed, the gas spread, and hospitals filled with the dying and the wounded), and (4) elaborating on a claim or extend reasoning (e.g., Because these weapons can kill on a mass scale, with no distinction between soldier and infant, the civilized world 
has spent a century working to ban them. And in 1997, the United States Senate overwhelmingly approved an international agreement prohibiting the use of chemical weapons, now joined by 189 governments that represent 98 percent of humanity).

Employing complementation constructions can influence listeners as they have rhetorical effects (Verhagen, 2010). Complementation constructions comprise a 'matrix-' and 'complement-' clause. The matrix-clause describes the speaker's stance towards a description of reality that is presented in the complement-clause. In Obama's speech, two stances have been found, and each stance represents a particular reality that projects two different viewpoints/perspectives and ideologies. Based on the grammatical subject in the matrix-clause, the speaker's two perspectives have been first-person speaker (singular and plural) and third-person speaker (singular and plural). The first-person speaker represents Obama and his allies, while the third-person speaker represents Al-Assad and his regime. The outcomes found in the complement-clauses that represent two realities (negative and positive) and associated with the speaker's two different stances are thought-provoking. They have had a rhetorical effect on the listeners which is to sway Americans to accept the military intervention in Syria. The examples in Table 1 illustrate the connotation of the complementation constructions.

Table 1. Examples of the connotation of the complementation constructions in Obama's speech

\begin{tabular}{|c|c|}
\hline Matrix-clause (speaker's stance) & Complement-clause (Reality) \\
\hline $\begin{array}{l}\text { First-person speaker representing Obama } \\
\text { and his allies' stance }\end{array}$ & Positive reality \\
\hline$I$ & $\begin{array}{l}\text { have a deeply held preference for peaceful solutions } \\
\text { the anchor of global security }\end{array}$ \\
\hline with modest effort and risk, we & can stop children from being gassed to death \\
\hline we & $\begin{array}{l}\text { would redouble our efforts to achieve a political solution that } \\
\text { strengthens those who reject the forces of tyranny and } \\
\text { extremism. }\end{array}$ \\
\hline $\begin{array}{c}\text { Third-person speaker representing Al-Assad } \\
\text { and his regime }\end{array}$ & Negative reality \\
\hline Then they & $\begin{array}{l}\text { fired rockets from a regime-controlled area into } 11 \\
\text { neighborhoods that the regime has been trying to wipe clear } \\
\text { of opposition forces } \\
\text { Atrocities }\end{array}$ \\
\hline When dictators & commit \\
\hline they & $\begin{array}{l}\text { depend upon the world to look the other way until those } \\
\text { horrifying pictures fade from memory }\end{array}$ \\
\hline the Assad regime & $\begin{array}{l}\text { will see no reason to stop using chemical weapons (implying } \\
\text { they had used them against the Syrians) }\end{array}$ \\
\hline when Assad's government & $\begin{array}{l}\text { gassed to death over a thousand people, including hundreds } \\
\text { of children }\end{array}$ \\
\hline
\end{tabular}

The analysis also indicates that Obama has opted for noun phrases to describe the other negatively and the identities belonging to his ideology positively. There are many examples that underscore this finding such as (e.g., the forces of tyranny and extremism, repressive regime of Bashar al-Assad, Assad's government (not the Syrian), terrible nature, a crime against humanity (describing the chemical attacks), a violation of the laws of war (describing the chemical attacks) as well as clauses that paint a grim picture of the out-group actions as (e.g., Men, women, children lying in rows, killed by poison gas, Others foaming at the mouth, gasping for breath and $A$ father clutching his dead children). Other examples of phrases that describe the in-group positively include noun phrases (e.g., peaceful protests, my fellow Americans, and the moderate opposition), and verb phrases (e.g., to provide humanitarian support, to help the moderate opposition and to shape a political settlement).

\subsubsection{Personal pronouns}

Personal pronouns are employed by the speaker to talk to or about people or things or even about himself. Two types of personal pronouns can be identified: subjective personal pronouns and objective personal pronouns. The subjective personal pronouns are employed to refer to a subject complement or subject of a clause, such as (e.g., l, we, you, he, she, it and they), while objective personal pronouns (e.g., me, us, you, him, her, it and them) are used to refer to the same people or things as the equivalent subject pronouns (Collins and Hollow, 2017, p. 29). 
The use of personal pronouns in language categorizes the ideological division, signaling the functions of inclusion and exclusion (Nhat, 2008). These functions in Obama's speech are the inclusion of Americans and their allies and the exclusion of Al-Assad regime. In his speech, he has used the first-person pronoun (e.g., we) to refer to the in-group, which contributed to drawing national solidarity among the members of the in-group at the time of instability. On the other hand, the third person pronouns (e.g., they and their) have been used to refer to the members of the out-group to separate the self or who belong to the in-group from others. Therefore, through this rhetorical device, Obama has created a feeling of intimacy with his audience, exhibiting sympathy and solidarity to make his audience remember significant information. The choice of pronouns is greatly shaped by the ideological relationship between the speaker and the addressee. Addressing someone using the pronouns of (e.g., I and we) shows solidarity, equality and intimacy; whereas, addressing someone using the third person pronouns (e.g., him and his) shows inequality and draws a social distance.

The use of pronouns (e.g., I, you and we) "expresses sociable styles and connotes a higher degree of intimacy, solidarity and sympathy" (Nhat 2008, p. 9). The combination of ( $I$ and You) suggests not merely strong emotion, but also a degree of informality between the speaker and the listener. The informal relation stands among friends, brothers or members of the same family/group. To illustrate, Obama deftly employs (My fellow Americans, tonight I want to talk to you about Syria -- why it matters, and where we go from here). By using the first singular person pronoun ( $I$ ) and second personal pronoun (you) in this sentence, Obama has seemingly succeeded in expressing his feeling and establishing an informal connection between Obama and the audience (Americans and their allies). Moreover, by using the first-person plural pronoun (we), he has managed to narrow the distance between himself and the audience to provoke a sense of collectivity as if he was standing beside the audience. In addition, by using the pronoun (we), he has tried to create a sense of togetherness in his audience. Hence, this has increased the likelihood of securing the approval of some Americans and senators who have opposed the military strike against Syria, especially after heavy losses sustained by American troops in Afghanistan and Iraq.

\subsubsection{Metaphorical expressions}

Metaphorical expressions are used to polarize the different ideologies. Obama has made use of different metaphorical expressions to emphasize some ideas and stands in the minds of the audience. He has metaphorically drawn a comparison between two unlikely items by using (fighting spills), where he compares fighting to a liquid that may spill to the neighboring countries of Syria. This highlights the deteriorating conditions in Syria and, again, stresses the need for military intervention to stem bloodshed. In addition, a personification is used to portray the opposing countries as humans. Thus, countries that are considered America's allies (Jordan, Israel and Turkey) could be threatened by the spread of the chemical weapons. Obama has stressed the need for his allies to stand against this threat. The overarching idea in his speech is that the Syrian regime and Iran are viewed as a threat hence, it has been imperative to take action. In the same vein, Obama has portrayed Iran and its allies in a negative light on one hand, and the U.S and its allies in a favorable light on the other hand. In so doing, he sets up a bipolar set of power relations which emphasizes the superiority of the U.S. and the inferiority of its enemies.

Another example of metaphorical expressions is the use of metonymy as in the use of (the world) metaphorically to intensify the idea of all people witnessing the crimes of the opposition (e.g., The world saw thousands of videos, cell phone pictures, and social media accounts from the attack, and humanitarian organizations told stories of hospitals packed with people who had symptoms of poison gas). This metonymy serves to expose the nefarious nature of the people who use chemical weapons.

Similarly, Obama has employed metaphorical language to whitewash the image of America as a superpower that has a dominant position in the international community as well as the ability to exercise control over whenever need be. In so doing, he has emphasized America's hegemony. America is described metaphorically as (e.g., the anchor of global security) in order to evoke the feeling that America is the balancing force in the world that establishes peace and stability. Also, in (e.g., the burdens of leadership are often heavy, but the world is a better place because we have borne them). America has also been described as the leader of the globe and the responsible party that ensures welfare for other countries.

Another example can be related to the use of hyperbole. In his speech, Obama has used the numbers of death toll to show his accuracy and to elicit sympathy for Syrian victims. He has referred to big numbers (e.g., 100000, millions and thousands) in order to exaggerate the situation and to remind the audience of the atrocities committed by the Syrian regime. Moreover, he has repeatedly used the words (over) and (many) to make the audience imagine bigger numbers of casualties. Obama has deftly employed these exaggerated numbers to stress the pressing need for the military strike.

\subsection{Intertextuality}

Intertextuality as defined by Genette, Lewin and Culler (2006) is the "presence of a text in another text" (p. 40), and it encompasses three concepts: direct quotation, reference and allusion. Intertextuality is particularly discernible in Obama's speech. It is one of 
the devices adopted to establish a sense of connection with his audience in order to convince them of his argument by "outlining common values with the support of history, cultural traditions, and religion" (Kitaeva and Ozerova, 2019, p. 143).

Obama has quoted from a speech delivered by Franklin Delano Roosevelt, who has been a central figure in world events during the mid-20th century and a dominant leader of the Democratic Party, on October 2, 1935, in San Diego. Roosevelt once said, (e.g., Our national determination to keep free of foreign wars and foreign entanglements cannot prevent us from feeling deep concern when ideals and principles that we have cherished are challenged). This quotation is related to a part of a section of Roosevelt's speech defending a non-interventionist 'good neighbor' policy in Latin America and non-interventionism more broadly. He has dexterously used our 'deep concern' to clarify that the involvement of all Americans will be limited to such concern, mainly because, as he says, 'other nations' policies contrary to our rules of conscience and conduct 'are beyond our jurisdiction'. Obama has apparently resorted to the Roosevelt' speech to rationalize the military intervention in Syria. He wants to reassert the hegemonic power of the US and the role it undertakes to establish world peace. This has been evident when he says in a manner close to Roosevelt (e.g., Our ideals and principles, as well as our national security, are at stake in Syria, along with our leadership of a world where we seek to ensure that the worst weapons will never be used).

Another reference, that Obama has made use of, corresponded to historical events (e.g., World War I, when the American soldiers were killed by deadly gas in Europe, World War II when the Nazis used gas to inflict the horror of the Holocaust, and in 1997 when the United States Senate approved an international agreement prohibiting the use of chemical weapons). The reference to such events has revived the Americans' memory of pain and fear that have been caused as a result of the mass destruction weapons. This has been instrumental in turning his audience, especially the senators of the Congress, against Al-Assad and his regime. In doing so, the Americans have been reminded of the enemies. Conjuring up these images of death and destruction has undoubtedly helped Obama sway Americans to approve the military action.

Obama has also referred to two war events (e.g., the terrible toll of Iraq and Afghanistan) to convince his audience of the necessity of an immediate action to put an end to the massacre in Syria. He has highlighted these two events to answer many questions raised by different parties and to ensure his audience that similar mistakes will be avoided (e.g., I will not pursue an open-ended action like Iraq or Afghanistan and I will not pursue a prolonged air campaign like Libya or Kosovo). He has even taken this a step further when he says (e.g., This would be a targeted strike to achieve a clear objective: deterring the use of chemical weapons, and degrading Assad's capabilities). Here, he wants to send a message that this will be a carefully studied plan and he has thus labeled it as a 'targeted strike'.

\subsection{Rhetorical questions}

A rhetorical question is considered a figure of speech that does not need an answer as it is used to encourage the listener to consider a message or viewpoint. The pragmatic function of this question is confirmation, denial, condemnation or satire. A carefully selected rhetorical question can persuade the listener to believe in the position of the speaker and do certain actions as in (e.g., What kind of world will we live in if the United States of America sees a dictator brazenly violate international law with poison gas, and we choose to look the other way?) where Obama has expressed his feelings of rejection and denunciation of Al-Assad's actions and to rally support for the military strike against Syria. Further, this rhetorical question promotes the image of America as the guardian of peace and stability in the world. Therefore, using this question underlines the fact that America is the superpower. It also stresses the necessity of launching a military strike since it portrays the Syrian regime as a threat to world peace and security. This is clear in (e.g., The question now is what the United States of America, and the international community, is prepared to do about $i t$ ), where he vehemently criticizes the inaction of the international community for the heinous crimes perpetrated in Syria.

\subsection{Parallelism/Repetition}

Parallelism is a rhetorical device that is used heavily in political discourse to reinforce ideas that are repeated in similar structures. It strengthens, emphasizes, and draws attention to a parallel structure that embodies particular views and stands. Parallelism is defined as "the repetition of identical or similar syntactic patterns in adjacent phrases, clauses or sentences" (Preminger, Hardison and Warnke, 2016, p. 877). This repetition can be defined as "multiple instances of an idea or word, and the greater the number of repetitions the more we notice it" (Reynolds, 1995, p. 185). Obama has employed several types of parallelism in his speech to reinforce his stands and to convince his audience of his view and mobilize support for his decisions.

One is referred to as lexical parallelism that includes the repetition of words that have a semantic contribution to the overall message. Repetition influences the cohesiveness of a text, in which lexical items create a cohesive link across sentences and paragraphs to aid listeners to follow meanings (Halliday and Hassan, 2014, p. 284). Lexical parallelism is analyzed as a repetition of the same word and a repetition of a synonymous word. Obama has employed the same word more than once in the same speech (e.g., Assad regime, Assad, the regime, and a regime). His choice has not been haphazard as it is deliberately used to stress the reprehensible nature of Al- Assad's regime. The word (Assad) has been repeated three times and the item (regime) has been 
repeated four times. The clauses that accompany these words denote killing and using chemical weapons. Repetition has been used here to bring to light the enormity of the crimes committed by Al-Assad and to draw people's attention to the fact that this regime is carrying out cold-blooded massacres. Moreover, calling Al-Assad as (Assad), not the president, indicates that Obama does not recognize Bashar as a legitimatized president of Syria. However, when he mentions another president, like Putin, he calls him (President Putin). Obama has availed himself of synonymous words to describe the violence of the Syrian regime and emphasize his point of view. For example, Al-Assad has been described as (a dictator, a tyrant, and the repressive regime) to alert Americans to the blatant human rights abuses by him and eventually gain their support.

Syntactic parallelism is a parallelism in form and structure at different levels: word, phrase and clause. It is used to persuade the audience and manipulate them. The use of infinitive at word level has been found in Obama's speech (e.g., The purpose of this strike would be to deter Assad from using chemical weapons, to degrade his regime's ability to use them, and to make clear to the world that we will not tolerate their use" and "In that time, America has worked with allies to provide humanitarian support, to help the moderate opposition, and to shape a political settlement). Parallelism at phrase level, which includes noun, verb, prepositional, adjectival and adverbial phrases, has also been detected in Obama's speech, which was rich with noun phrases that consisted of article + adjective + noun structure (e.g., On that terrible night, the world saw in gruesome detail the terrible nature of chemical weapons, and why the overwhelming majority of humanity has declared them off-limits -- a crime against humanity, and a violation of the laws of war). Obama has made use of such parallelism to achieve unity and coherence and therefore have a greater impact on the audience. Parallelism has also been employed at clause level in Obama's speech (e.g., And so, to my friends on the right, I ask you to reconcile your commitment to America's military might with a failure to act when a cause is so plainly just. To my friends on the left, I ask you to reconcile your belief in freedom and dignity for all people with those images of children writhing in pain, and going still on a cold hospital floor, and that's what makes America different. That's what makes us exceptional).

\section{Conclusion}

Using Fairclough's (2001) framework of CDA, this study has investigated the ideological polarization latent in the language of Obama's speech on Syria delivered on September 10, 2013 in response to the chemical attacks committed in Damascus on August 23 , 2013. As for the first question, how was Obama's language used to display the nature of the US political discourse during the Syrian crisis?, it is clear that Obama has been aware that expressing US political position has been insufficient to get the broadbased support of the general public. Therefore, the analysis indicates that he has cleverly manipulated their perception of events to exercise some ideological pressure using a myriad of linguistic devices (e.g., stylistic, pragmatic and rhetorical). These devices have had a substantial impact on the receivers as they have involved them mentally and emotionally. The study also demonstrates that Obama's language has managed to cast more light on the adherence of the in-group to the values of peace and democracy and the flagrant disregard for these values from the out-group using various linguistic devices. The language employed in Obama's speech on Syria condemned the violent and chemical attacks against civilians and those who committed them differentiated morally and ideologically between two opposing groups. As for the second question, what was the ideological component enshrined in Obama's language over the Syrian crisis?, the study shows that the use of rhetorical devices instigated by ideological beliefs have helped identify Obama and the US's ideological standpoint. This has been evident, for example, in the choice of lexical devices that highlighted the concepts of polarization and inclusiveness. Obama's lexical choices have drawn a distinction between two ideologies, the in-group and the out-group. He has polarized on to the side of Americans whereas Al-Assad and his followers have been discarded from this side as their acts have run counter to the ideological stands of America. Further, the use of personal pronouns 'we' and 'us' has underlined the notion of inclusiveness which has been instrumental in gaining public and congressional approval. Moreover, the use of intertextuality in Obama's speech has formed connectedness with his people to convince them of his argument. The study has also come up with some findings with regard to the third question, what were the typical discourse strategies used by Obama to persuade the world community or to build an international coalition against the Syrian regime? Obama's most notable discourse strategies have been the use of rhetorical questions, parallelism and metaphorical expressions. His use of rhetorical questions aimed at making the listener adopt certain action(s) regarding what happened in Damascus following the chemical attacks. As for parallelism, Obama has employed a variety of paralleled structures in his speech to sway the audience to his views and win their support. The use of parallelism has added to the cohesiveness and interrelatedness of his speech, which in turn has had greater impact on people's mindset. Adding to this, the use of metaphorical expressions has helped to influence people's viewpoints by creating mental images that have portrayed Al-Assad's regime in a negative light.

\section{References}

[1] Abdul Wahid, H. (2012). Exploring the use of euphemisms in some speeches of president Obama: A pragmatic study. Al-Mustansiriya Journal of Arts, (58), 1-14.

[2] Baker, P., \& Ellece, S. (2013). Key terms in discourse analysis. London: Bloomsbury Academic.

[3] Batluk, L. (2011). Rhythm and Rhetoric: A Linguistic Analysis of Barack Obama's Inaugural Address. University essay. Högskolan Halmstad Sektionenförhumaniora HUM. 
[4] Collins, P., \& Hollo, C. (2017). English grammar. Basingstoke: Palgrave Macmillan.

[5] Escudero, M. (2011). Barack Obama's inaugural address: Metaphor and values as captivating strategies to celebrate a presidency. Pragmalingüística, (19), 44-55.

[6] Fairclough, N. (2018). Critical discourse analysis: The critical study of language. London: Routledge.

[7] Fairclough, N. (2015). Language and power. Abington, Oxon: Routledge Taylor \& Francis Group.

[8] Fairclough, N. (2001). Critical discourse analysis as a method in social scientific research. In Wodak, R., Meyer, M. (Eds.), Methods of critical discourse analysis (pp. 122-136). London, England: Sage.

[9] Genette, G., Lewin, J., \& Culler, J. (2006). Narrative discourse: An essay in method. Ithaca: Cornell University Press.

[10] Halliday, M. \& Halliday, R. (1993). Cohesion in English. Harlow: Longman.

[11] Horváth, J. (2009). Critical discourse analysis of Obama's political discourse. In Language, Literature and Culture in a Changing Transatlantic World International Conference Proceedings, University Library of Prešov University, 22-23.

[12] Kitaeva, E., \& Ozerova, O. (2019). Intertextuality in Political Discourse. In Language, Power, and Ideology in Political Writing: Emerging Research and Opportunities, 143-170. IGI Global.

[13] Lakoff, G. (1995). Metaphor, morality, and politics, or, why conservatives have left liberals in the dust. Social Research, 177-213.

[14] Matić, D. (2012). Ideological discourse structures in political speeches. Komunikacija i kultura online, 3(3), 54.

[15] Nguyen, T. (2012). A study of some linguistic features of Barack Obama's English speeches. [Doctoral dissertation]. University of Đà Nẵng, Vietnam.

[16] Nhat, L. (2008). The use of pronouns, parallelism in Obama's two political speeches. Hogskolan Dalarna University Journal, 17(3), 67-80.

[17] Obama, B. (2013). Remarks by the president in address to the nation on Syria. [Transcript]. Retrieved From https://obamawhitehouse.archives.gov/the-press-office/2013/09/10/remarks-president-address-nation-syria

[18] Preminger, A., Hardison, O., \& Warnke, F. (2016). Princeton Encyclopedia of Poetry and Poetics. London: Macmillan Education, Limited.

[19] Reynolds, D. (1995). Repetition in Nonnative Speaker Writing: More than Quantity. Studies in Second Language Acquisition, 17(2), 185-209.

[20] Sarfo, E., \& Krampa, E. (2012). Language at War: A Critical Discourse Analysis of Speeches of Bush and Obama on Terrorism. International Journal of Social Sciences \& Education, 3(2), 378-390.

[21] Shayegh, K., \& Nabifar, N. (2012). Power in Political Discourse of Barack Obama. Journal of Basic and Applied Scientific Research 2(4), 34813491.

[22] Sheyholislami, J. (2010). Identity, language, and new media: The Kurdish case. Language Policy, 9(4), 289-312.

[23] Suleiman, Y. (2003). The Arabic language and national identity: A study in ideology. Edinburgh: Edinburgh University Press.

[24] Van Dijk, T. (2000). Ideology and discourse: A multidisciplinary introduction. Pompeu Fabra University, Barcelona, 1025-1034.

[25] Van Dijk, T. (1993). Principles of Critical Discourse Analysis. Discourse \& Society, 4(2), 249-283.

[26] Verhagen, A. (2010). Constructions of intersubjectivity: Discourse, syntax, and cognition. New York: Oxford University Press.

[27] Wang, J. (2010). A critical discourse analysis of Barack Obama's speeches. Journal of language teaching and research, 1(3), $254-261$.

\section{Appendix}

Remarks by the President in Address to the Nation on Syria

\section{The White House}

Office of the Press Secretary

September 10, 2013 
9:01 P.M. EDT

THE PRESIDENT: My fellow Americans, tonight I want to talk to you about Syria -- why it matters, and where we go from here. Over the past two years, what began as a series of peaceful protests against the repressive regime of Bashar al-Assad has turned into a brutal civil war. Over 100,000 people have been killed. Millions have fled the country. In that time, America has worked with allies to provide humanitarian support, to help the moderate opposition, and to shape a political settlement. But I have resisted calls for military action, because we cannot resolve someone else's civil war through force, particularly after a de cade of war in Iraq and Afghanistan.

The situation profoundly changed, though, on August 21st, when Assad's government gassed to death over a thousand people, including hundreds of children. The images from this massacre are sickening: Men, women, children lying in rows, killed by poison gas. Others foaming at the mouth, gasping for breath. A father clutching his dead children, imploring them to get up and walk. On that terrible night, the world saw in gruesome detail the terrible nature of chemical weapons, and why the overwhelming majority of humanity has declared them off-limits -- a crime against humanity, and a violation of the laws of war. This was not always the case. In World War I, American Gls were among the many thousands killed by deadly gas in the trenches of Europe. In World War II, the Nazis used gas to inflict the horror of the Holocaust. Because these weapons can kill on a mass scale, with no distinction between soldier and infant, the civilized world has spent a century working to ban them. And in 1997, the United States Senate overwhelmingly approved an international agreement prohibiting the use of chemical weapons, now joined by 189 governments that represent 98 percent of humanity.

On August 21st, these basic rules were violated, along with our sense of common humanity. No one disputes that chemical weapons were used in Syria. The world saw thousands of videos, cell phone pictures, and social media accounts from the attack, and humanitarian organizations told stories of hospitals packed with people who had symptoms of poison gas.

Moreover, we know the Assad regime was responsible. In the days leading up to August 21st, we know that Assad's chemical weapons personnel prepared for an attack near an area where they mix sarin gas. They distributed gasmasks to their troops. Then they fired rockets from a regime-controlled area into 11 neighborhoods that the regime has been trying to wipe clear of opposition forces. Shortly after those rockets landed, the gas spread, and hospitals filled with the dying and the wounded. We know senior figures in Assad's military machine reviewed the results of the attack, and the regime increased their shelling of the same neighborhoods in the days that followed. We've also studied samples of blood and hair from people at the site that tested positive for sarin.

When dictators commit atrocities, they depend upon the world to look the other way until those horrifying pictures fade from memory. But these things happened. The facts cannot be denied. The question now is what the United States of America, and the international community, is prepared to do about it. Because what happened to those people -- to those children -- is not only a violation of international law, it's also a danger to our security.

Let me explain why. If we fail to act, the Assad regime will see no reason to stop using chemical weapons. As the ban against these weapons erodes, other tyrants will have no reason to think twice about acquiring poison gas, and using them. Over time, our troops would again face the prospect of chemical warfare on the battlefield. And it could be easier for terrorist organizations to obtain these weapons, and to use them to attack civilians.

If fighting spills beyond Syria's borders, these weapons could threaten allies like Turkey, Jordan, and Israel. And a failure to stand against the use of chemical weapons would weaken prohibitions against other weapons of mass destruction, and embolden Assad's ally, Iran -- which must decide whether to ignore international law by building a nuclear weapon, or to take a more peaceful path.

This is not a world we should accept. This is what's at stake. And that is why, after careful deliberation, I determined that it is in the national security interests of the United States to respond to the Assad regime's use of chemical weapons through a targeted military strike. The purpose of this strike would be to deter Assad from using chemical weapons, to degrade his regime's ability to use them, and to make clear to the world that we will not tolerate their use.

That's my judgment as Commander-in-Chief. But I'm also the President of the world's oldest constitutional democracy. So even though I possess the authority to order military strikes, I believed it was right, in the absence of a direct or imminent threat to our security, to take this debate to Congress. I believe our democracy is stronger when the President acts with the support of Congress. And I believe that America acts more effectively abroad when we stand together.

This is especially true after a decade that put more and more war-making power in the hands of the President, and more and more burdens on the shoulders of our troops, while sidelining the people's representatives from the critical decisions about when we use force.

Now, I know that after the terrible toll of Iraq and Afghanistan, the idea of any military action, no matter how limited, is not going to be popular. After all, I've spent four and a half years working to end wars, not to start them. Our troops are out of Iraq. Our troops are coming home from Afghanistan. And I know Americans want all of us in Washington

-- especially me -- to concentrate on the task of building our nation here at home: putting people back to work, educating our kids, growing our middle class.

Page | 110 
It's no wonder, then, that you're asking hard questions. So let me answer some of the most important questions that I've heard from members of Congress, and that I've read in letters that you've sent to me.

First, many of you have asked, won't this put us on a slippery slope to another war? One man wrote to me that we are "still recovering from our involvement in Iraq." A veteran put it more bluntly: "This nation is sick and tired of war."

My answer is simple: I will not put American boots on the ground in Syria. I will not pursue an open-ended action like Iraq or Afghanistan. I will not pursue a prolonged air campaign like Libya or Kosovo. This would be a targeted strike to achieve a clear objective: deterring the use of chemical weapons, and degrading Assad's capabilities.

Others have asked whether it's worth acting if we don't take out Assad. As some members of Congress have said, there's no point in simply doing a "pinprick" strike in Syria.

Let me make something clear: The United States military doesn't do pinpricks. Even a limited strike will send a message to Assad that no other nation can deliver. I don't think we should remove another dictator with force -- we learned from Iraq that doing so makes us responsible for all that comes next. But a targeted strike can make Assad, or any other dictator, think twice before using chemical weapons.

Other questions involve the dangers of retaliation. We don't dismiss any threats, but the Assad regime does not have the ability to seriously threaten our military. Any other retaliation they might seek is in line with threats that we face every day. Neither Assad nor his allies have any interest in escalation that would lead to his demise. And our ally, Israel, can defend itself with overwhelming force, as well as the unshakeable support of the United States of America.

Many of you have asked a broader question: Why should we get involved at all in a place that's so complicated, and where -as one person wrote to me -- "those who come after Assad may be enemies of human rights?"

It's true that some of Assad's opponents are extremists. But al Qaeda will only draw strength in a more chaotic Syria if people there see the world doing nothing to prevent innocent civilians from being gassed to death. The majority of the Syrian people -- and the Syrian opposition we work with -- just want to live in peace, with dignity and freedom. And the day after any military action, we would redouble our efforts to achieve a political solution that strengthens those who reject the forces of tyranny and extremism.

Finally, many of you have asked: Why not leave this to other countries, or seek solutions short of force? As several people wrote to me, "We should not be the world's policeman."

I agree, and I have a deeply held preference for peaceful solutions. Over the last two years, my administration has tried diplomacy and sanctions, warning and negotiations -- but chemical weapons were still used by the Assad regime.

However, over the last few days, we've seen some encouraging signs. In part because of the credible threat of U.S. military action, as well as constructive talks that I had with President Putin, the Russian government has indicated a willingness to join with the international community in pushing Assad to give up his chemical weapons. The Assad regime has now admitted that it has these weapons, and even said they'd join the Chemical Weapons Convention, which prohibits their use.

It's too early to tell whether this offer will succeed, and any agreement must verify that the Assad regime keeps its commitments. But this initiative has the potential to remove the threat of chemical weapons without the use of force, particularly because Russia is one of Assad's strongest allies.

I have, therefore, asked the leaders of Congress to postpone a vote to authorize the use of force while we pursue this diplomatic path. I'm sending Secretary of State John Kerry to meet his Russian counterpart on Thursday, and I will continue my own discussions with President Putin. I've spoken to the leaders of two of our closest allies, France and the United Kingdom, and we will work together in consultation with Russia and China to put forward a resolution at the U.N. Security Council requiring Assad to give up his chemical weapons, and to ultimately destroy them under international control. We'll also give U.N. inspectors the opportunity to report their findings about what happened on August 21 st. And we will continue to rally support from allies from Europe to the Americas -- from Asia to the Middle East -- who agree on the need for action.

Meanwhile, I've ordered our military to maintain their current posture to keep the pressure on Assad, and to be in a position to respond if diplomacy fails. And tonight, I give thanks again to our military and their families for their incredible strength and sacrifices.

My fellow Americans, for nearly seven decades, the United States has been the anchor of global security. This has meant doing more than forging international agreements -- it has meant enforcing them. The burdens of leadership are often heavy, but the world is a better place because we have borne them.

And so, to my friends on the right, I ask you to reconcile your commitment to America's military might with a failure to act when a cause is so plainly just. To my friends on the left, I ask you to reconcile your belief in freedom and dignity for all people with those images of children writhing in pain, and going still on a cold hospital floor. For sometimes resolutions and statements of condemnation are simply not enough.

Indeed, I'd ask every member of Congress, and those of you watching at home tonight, to view those videos of the attack, and then ask: What kind of world will we live in if the United States of America sees a dictator brazenly violate international law with poison gas, and we choose to look the other way?

Franklin Roosevelt once said, "Our national determination to keep free of foreign wars and foreign entanglements cannot prevent us from feeling deep concern when ideals and principles that we have cherished are challenged." Our ideals and 
principles, as well as our national security, are at stake in Syria, along with our leadership of a world where we seek to en sure that the worst weapons will never be used.

America is not the world's policeman. Terrible things happen across the globe, and it is beyond our means to right every wrong. But when, with modest effort and risk, we can stop children from being gassed to death, and thereby make our own children safer over the long run, I believe we should act. That's what makes America different. That's what makes us exceptional. With humility, but with resolve, let us never lose sight of that essential truth.

Thank you. God bless you. And God bless the United States of America.

END $\quad 9: 17$ P.M. EDT 